NIST Advanced Manufacturing Series 600-1

\author{
Charter of the \\ Institute Directors Council \\ Manufacturing USA
}

Craig Blue, IACMI

Larry Brown, LIFT

Yoel Fink, AFFOA

Nick Justice, PowerAmerica

Michael Liehr, AIM Photonics

Tom McDermott, DMDII

Ed Morris, America Makes

This publication is available free of charge from:

https://doi.org/10.6028/NIST.AMS.600-1

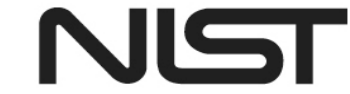

National Institute of Standards and Technology

U.S. Department of Commerce 


\section{Charter of the Institute Directors Council Manufacturing USA}

Prepared for

U.S. Department of Commerce Advanced Manufacturing National Program Office

National Institute of Standards and Technology

Gaithersburg, MD 20899

Craig Blue, IACMI

Larry Brown, LIFT

Yoel Fink, AFFOA

Nick Justice, PowerAmerica Michael Liehr, AIM Photonics

Tom McDermott, DMDII

Ed Morris, America Makes

This publication is available free of charge from: https://doi.org/10.6028/NIST.AMS.600-1

November 2016

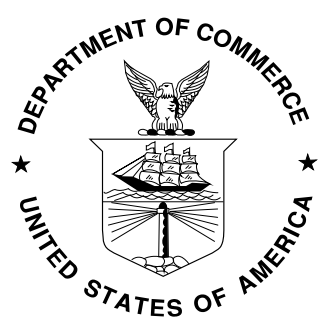

U.S. Department of Commerce Penny Pritzker, Secretary

National Institute of Standards and Technology Willie May, Under Secretary of Commerce for Standards and Technology and Director 


\section{Disclaimer}

This publication was produced as part of Manufacturing USA. The contents of this publication do not necessarily reflect the views or policies of the National Institute of Standards and Technology or the US Government. 


\section{Charter of the Institute Directors Council Manufacturing USA}

\section{A. Official Designation}

For the purpose of supporting Manufacturing USA and in accordance with the Revitalize American Manufacturing and Innovation Act of 2014 ${ }^{1}$, (RAMI) Act of 2014, 15 USC Sec. $278 \mathrm{~s}(\mathrm{f})(2)(\mathrm{C})$, this Charter establishes the Manufacturing USA Institute Directors Council, comprised of the directors from each Manufacturing USA Institute existing on the date this Charter is adopted and as may be admitted in the future pursuant to the criteria for admission set forth in the Revitalize American Manufacturing and Innovation Act of 2014 (RAMI).

\section{B. Mission and Role}

The Manufacturing USA program is composed of the collective of all of the manufacturing innovation institutes and a supporting Network. The Network serves the Institutes, the Institutes connect through the Network, and the Program serves the Nation.

- The Council's role is to support the Manufacturing USA goals which include (a) improving the competitiveness of United States manufacturing, (b) stimulating United States' leadership in advanced manufacturing research, innovation and technology, (c) accelerating the development of an advanced manufacturing workforce, (d) leveraging non-federal resources to sustain advanced manufacturing technologies while decreasing long-term federal funding and (e) creating and preserving jobs.

- In practice, the Manufacturing USA Institute Directors Council (hereinafter Council) will facilitate cooperation and collaboration among the Institutes, with advice as needed from the federal sponsors of Manufacturing USA, agencies providing funding of the Institutes, and from the Advanced Manufacturing National Program Office (AMNPO) housed at the National Institute of Standards and Technology (NIST). The AMNPO, serving as the Manufacturing USA National Program Office, will provide staff and financial support to the Council.

\section{Responsibilities}

The Council responsibilities include the following:

1. Promote collaboration and cooperation among the Institutes in support of the goals of Manufacturing USA;

2. Facilitate communications/engagement among the Institutes and between the Institutes and the Federal Government;

\footnotetext{
1 "Public Law No: 113-235: Consolidated and Further Continuing Appropriations Act, 2014, Division B, Title VII-Revitalize American Manufacturing and Innovation Act of 2014, Pp. 2220-2234.” Legislation, December 16, 2014. https://www.congress.gov/113/plaws/publ235/PLAW-113publ235.pdf.
} 
3. Encourage Institute activities that leverage the diversity and strengths of the Network to collaborate on cross-cutting activities;

4. Facilitate the Institutes' collaboration with the Manufacturing Extension Partnership (MEP) program and other established regional assets;

5. Support collaborative efforts on workforce development that provide enhanced experiential learning opportunities across the Network;

6. Recommend to the Network common policies/guidelines for Institutes;

7. Develop best practices and approaches for project calls involving two or more Institutes and support as appropriate (with input from the respective project funding agency) joint project calls by Institutes with existing resources;

8. Appoint committees to advise the Council on matters within its mission and to carry out responsibilities of the Council;

9. Adopt such other policies and rules and perform such other activities as are reasonably incidental to the administration and governance of the Manufacturing USA Council.

\section{Council Membership}

\section{Eligibility.}

All Manufacturing USA Manufacturing Innovation Institutes as recognized by the RAMI Act of 2014 are eligible for membership in the Manufacturing USA Council and, upon executing the governing documents (including Membership Agreement and Bylaws) become members. When a new Institute appoints a Director, that Director becomes the Institute's ex officio representative on the Council. In the event a vacancy occurs on the Council due to the lack of an Institute Director, the affected Institute may be represented by a Deputy Director or other officer of the Institute until a Director is appointed.

\section{Attendance.}

In order for the Council to effectively carry out its mission, participation by all members is of paramount importance. The expectation is that the Directors of the Institutes will regularly attend scheduled meetings. Directors may, however, designate an alternate officer of the Institute to attend any scheduled meeting.

\section{Compensation.}

The Council will not provide compensation for the expenses associated with the Institutes' participation in the Council, including attendance at meetings; individual Institutes will be responsible for reimbursing the expenses of their own participation. However, the Institute Council Chair will be reimbursed by the AMNPO for specific labor and travel expenses incurred to fulfill the duties of the Council Chair. The AMNPO will provide staff support to the Council. 


\section{E. Officers}

\section{Election of Chair and Term of Office}

The Council will elect a Chair from among the Institute Director members. The Chair will serve a one-year term with the option of being elected for a second one-year term. The Chair will be responsible for convening regular meetings and will have general supervision over the conduct of the business and affairs of the Council.

\section{Appointment of other Officers/Committees}

The Chair shall appoint a Vice-Chair and make any other administrative appointments that he/she deems necessary to carry out the duties of the office.

\section{F. Meetings}

\section{Regular}

A regular annual meeting of the Council will be held on a date and at a location to be determined by the Council.

\section{Other}

Other meetings may be called by the Council Chair as needed. Unless extraordinary circumstances prevent, all called meetings shall provide at least ten (10) days advance notice to Council members.

\section{Actions Require Majority}

Any action required or permitted to be taken by the Council must obtain affirmative votes by a majority of all members. Voting will be recorded by the Secretary, as will minutes of all regularly scheduled meetings.

\section{Amendments}

The requirements for amending this Charter are the same as those for all other actions taken. No vote on amendment may be taken unless members have been given at least ten (10) days' notice prior to the vote.

\section{ADOPTED}

